\title{
Pelatihan Instalasi Listrik Rumah Tangga untuk Pemuda di Kecamatan Manggala Makassar sebagai Upaya Penciptaan Lapangan Kerja Baru
}

\author{
Yusran*, Andani Ahmad, Indar Chaerah Gunadin, Muh. Bachtiar Nappu, Ardiaty Arief, Intan \\ Sari Areni, Hasniaty A, Ida Rahmaniar Sahali dan Andini Dani Achmad \\ Departemen Teknik Elektro Fakultas Teknik Universitas Hasanuddin \\ E-mail: yusranibnu@yahoo.com*
}

\begin{abstract}
Abstrak
Instalasi listrik rumah tangga harus dipasang secara baik dan benar oleh orang yang telah menjalani pelatihan khusus. Di sisi lain, pemasangan instalasi listrik rumah tangga merupakan peluang bagi tumbuhnya lapangan kerja baru khususnya bagi para pemuda. Latar belakang ini yang mendasari pelaksanaan pengabdian masyarakat dengan topik: Pelatihan Instalasi Listrik Rumah Tangga untuk Pemuda di Kecamatan Manggala Makassar sebagai Upaya Penciptaan Lapangan Kerja Baru. Perencanaan instalasi listrik rumah tangga setidak-tidaknya memiliki tahapan berupa pembuatan gambar rencana (peletakan alat listrik, single line diagram, perincian) dan pemasangan sesuai gambar rencana yang telah dibuat. Tahapan tersebut telah diadopsi dalam pelatihan ini. Kegiatan dengan peserta dari pemuda di Kecamatan Manggala telah dilaksanakan di Aula Gedung Yayasan Azhar Center Makassar. Metode pelatihan instalasi listrik rumah tangga ini menggunakan dua pendekatan yaitu teori dan praktek. Materi teori yang diberikan ada dua yaitu dasar-dasar instalasi listrik dan dasar pemasangan instalasi listrik rumah tangga. Adapun praktik berupa pemasangan instalasi penerangan listrik untuk rumah tangga. Pengukuran hasil pelatihan dilakukan di bagian akhir melalui metode kuesioner berbasis pertanyaan tertutup. Hasil pelatihan menunjukkan hasil yang memuaskan. Tingkat pengetahuan peserta setelah mengikuti pelatihan menunjukkan 14,3\% kategori cukup, 57,1 \% kategori baik dan 28,6 \% kategori baik sekali. Hal ini menunjukkan adanya indikasi awal kesiapan peserta untuk menerapkan ilmu yang telah didapatkannya. Secara umum dan menyeluruh dapat disimpulkan bahwa pelatihan ini telah berjalan dengan baik. Hal ini ditunjukkan oleh sejumlah indikator yaitu peningkatan tingkat pengetahuan peserta, penyajian materi, ketersediaan modul, kebermanfaatan pelatihan dan proses pelaksanan pelatihan.
\end{abstract}

Kata Kunci: pelatihan; teori dan praktek; instalasi listrik rumah tangga; instalasi penerangan; lapangan kerja.

\begin{abstract}
The household electrical installations must be installed properly and correctly by people who have undergone special training. On the other hand, the installation of household electrical installations is an opportunity for the growth of new jobs, especially for yuoth. This background that underlies the implementation of community service with the topic: Training of Household Electrical Installations for Youth in Manggala District Makassar as an Effort of New Jobs Creating. The household electrical installation planning at least has the stages in the form of drawing plans (laying of electrical devices, single line diagrams, details) and installation according to the drawings of plans that have been made. This stage has been adopted in this training. This household electrical installation training method uses two approaches namely theory and practice. The theoretical material provided there are two, namely the basics of electrical installation and basic installation of household electrical installations. The practice of installing electrical lighting installations for households. Measurement of training results is carried out at the end through a closed question-based questionnaire method. The results of the training showed satisfactory results. The level of knowledge of the participants after attending the training showed $14.3 \%$ of the sufficient categories, 57.1\% of the good categories and 28.6\% of the very good categories. This shows the initial indication of participants' readiness to apply the knowledge they have gained. In general and overall it can be concluded that this training has been going well. This is indicated by a number of indicators namely increasing the level of participant knowledge, presentation of materials, availability of modules, usefulness of the training and the process of implementing the training.
\end{abstract}

Keywords: training;theory and practice; household electrical installations; lighting installation; employment.

\section{Pendahuluan}


Energi listrik merupakan salah satu kebutuhan penting untuk kehidupan manusia dewasa ini. Daya listrik dibangkitkan di pusat-pusat beban dan selanjutnya ditransmisikan menuju gardu induk dengan menggunakan tegangan tinggi atau ekstra tinggi. Dari gardu induk, daya listrik tersebut disalurkan ke gardu distribusi melalu jaringan tegangan menengah $20 \mathrm{kV}$. Di gardu distribusi, tegangan diturunkan menjadi tegangan $220 \mathrm{~V}$ untuk selanjutnya disalurkan ke pelanggan termasuk untuk kebutuhan rumah tangga (Zuhal, 2000). Pada setiap rumah tangga terdapat instalasi listrik rumah tangga dengan beban utama berupa alat-alat listrik rumah tangga antara lain lampu, mesin cuci, AC dan pompa air.

Instalasi listrik yang standar sangat dibutuhkan agar listrik yang disalurkan tersebut dapat dinikmati dengan baik dan handal. Instalasi listrik yang standar juga berperan untuk mencegah terjadinya kebakaran akibat hubung singkat. Standar instalasi listrik yang berlaku di Indonesia saat ini adalah Peraturan Umum Instalasi Listrik (PUIL) 2000 (BSN, 2000). Dalam praktek sehari-sehari, kadangkala ditemukan adanya oknum masyarakat yang berani untuk memasang tambahan instalasi listriknya sendiri seperti menambah mata lampu dan stok kontak. Hal ini tentu perlu mendapatkan perhatian karena pemasangan instalasi listrik yang tidak didasari oleh pengetahuan yang benar berpotensi untuk menimbulkan bahaya (Linsley, 2004).

Di sisi pembahasan yang berbeda, permasalahan pengangguran adalah masalah yang umum dihadapi di kota-kota besar termasuk Makassar. Jumlah penduduk yang banyak tidak diimbangi oleh ketersediaan lapangan kerja. Hal ini akan berakibat timbulnya pengangguran baik terbuka maupun tertutup. Tak jarang pengangguran itu justru didominasi oleh para pemuda yang memiliki tingkat pendidikan SMA atau perguruan tinggi.

Salahsatu langkah yang bisa dilakukan adalah menginisiasi orang-orang yang mampu menciptakan lapangan kerjanya sendiri. Tantangannya adalah masih kurangnya pelatihan untuk memberikan bekal yang cukup kepada calon wiraswasta tersebut. Hal ini juga dirasakan oleh para pemuda di Kecamatan Manggala sehingga perlu mendapatkan solusi yang efektif. Hadirnya pelatihan di bidang instalasi rumah tangga dasar diharapkan menjadi salahsatu solusi kecil yang dibutuhkan.

Berdasarkan latar belakang diatas maka program pengabdian masyarakat dengan topik: Pelatihan Instalasi Listrik Rumah Tangga untuk Pemuda di Kecamatan Manggala Makassar sebagai Upaya Penciptaan Lapangan Kerja Baru ini mempunyai dua tujuan utama yaitu:

1) Memberikan dasar pengetahuan instalasi listrik rumah tangga yang dapat dimanfaatkan oleh peserta pelatihan dalam menangani instalasi listrik di tempat tinggalnya masing-masing.

2) Sebagai bekal dasar bilamana peserta pelatihan berminat untuk bekerja secara profesional sebagai instalatir listrik rumah tangga.

\section{Dasar Teori}

Sebelum pemasangan instalasi listrik rumah tangga maka terlebih dahulu dimulai dengan pembuatan gambar rencana (Harten dan Setiawan, 1991). Gambar rencana harus menyesuaikan dengan kondisi, konstruksi dan denah bangunan eksisting.

Sejumlah gambar instalasi listrik rumah tangga yang dibutuhkan antara lain gambar situasi yang menggambarkan lokasi rumah serta tiang distribusi jaringan tegangan rendah (JTR) terdekat. Gambar lainnya adalah gambar instalasi listrik dalam rumah yang meliputi gambar perencanaan, single line diagram dan gambar perincian yang dilengkapi dengan keterangan (Muliyana, 2010). 
a) Gambar instalasi sebagaimana ditunjukkan pada Gambar 1 meliputi (Muliyana, 2010) :

- Desain peletakan peralatan listrik yang dan sarana peralatannya. Contohnya titik lampu, sakelar, stop kontak.

- Desain penyambungan peralatan listrik dengan alat pelayanannya. Contohnya antara lain lampu dengan sakelarnya.

- Hubungan antara peralatan listrik dan sarana pelayanannya dengan perlengkapan hubung bagi

- Informasi teknik dari peralatan listrik yang rencana dipasang.

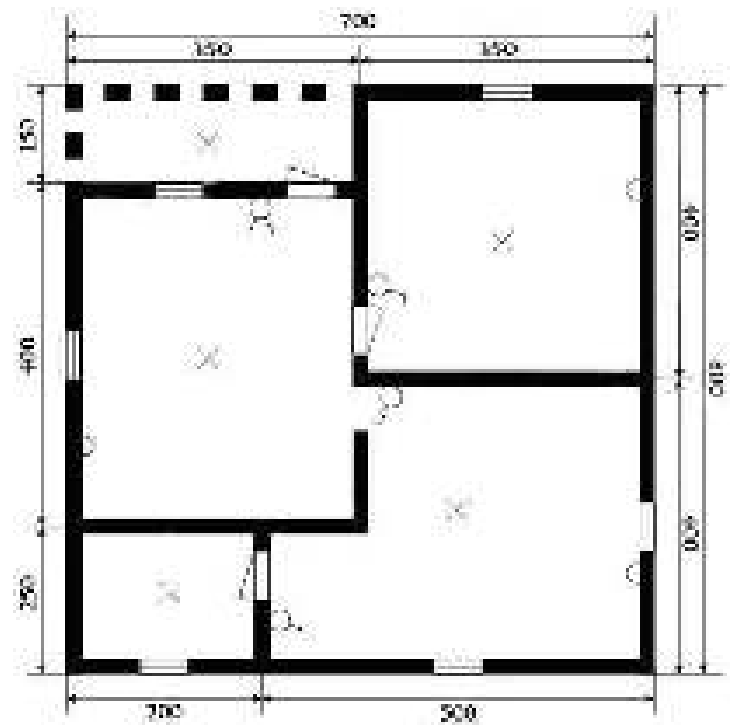

Gambar 1. Perencanaan Letak Peralatan Instalasi Dalam Rumah

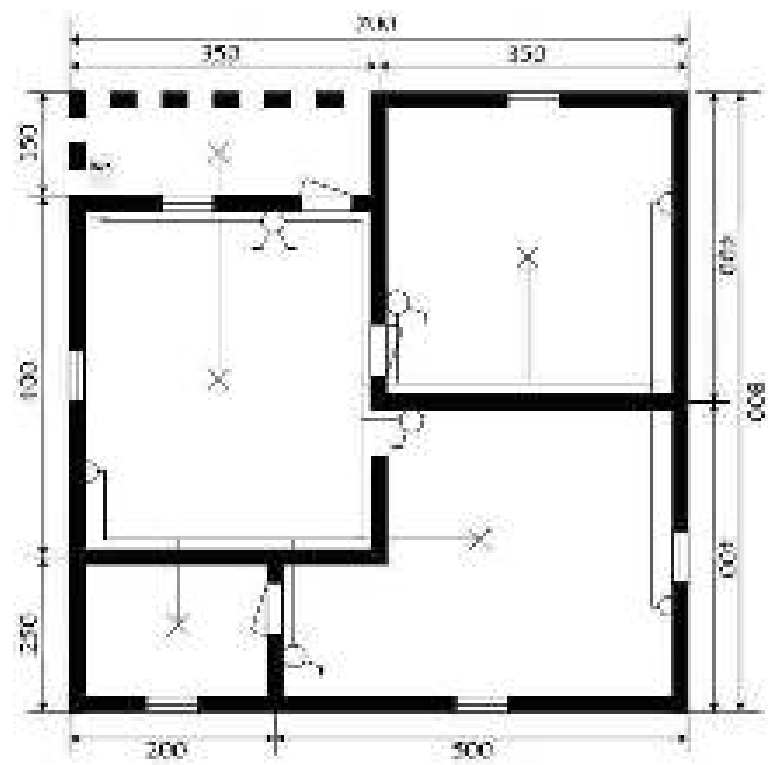

Gambar 2. Single Line Diagram 


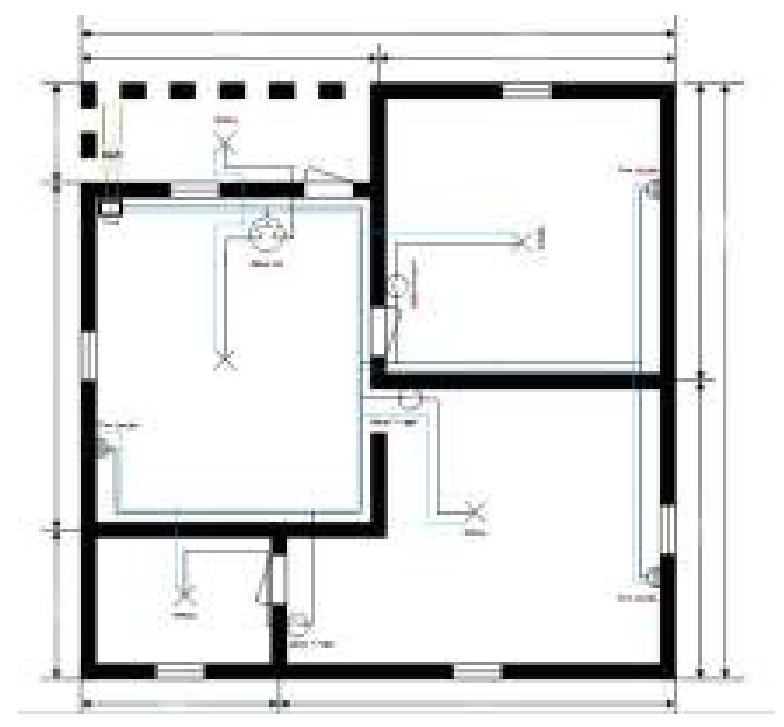

Gambar 3. Diagram Perincian

b) Single line diagram ditunjukkan pada Gambar 2. Single line diagram meliputi (Muliyana, 2010):

- Skema perlengkapan hubung bagi yang dilengkapi dengan informasi besar daya nominal komponen.

- Informasi beban yang terpasang dan pembaginya.

- Ukuran dan jenis konduktor

- Sistem pembumian.

c) Gambar perincian atau keterangan yang diperlukan ditunjukkan pada Gambar 3 dan meliputi: (Muliyana, 2010):

- Prediksi kuantitas fisik perlengkapan hubung bagi.

- Teknik pemasangan peralatan listrik

- Teknik pemasangan penghantar.

\section{Metode Kegiatan}

\subsection{Tahapan Persiapan}

Tahapan persiapan terdiri atas kegiatan sebagai berikut:

1) Koordinasi dan sosialisasi pendahuluan dengan mitra kegiatan dan masyarakat yang menjadi obyek dari kegiatan pengabdian masyarakat ini.

2) Pembuatan modul pelatihan instalasi listrik rumah tangga tingkat dasar

\subsection{Tahap pelaksanaan}

Pelaksanaan pelatihan dengan menggunakan pendekatan secara teori dan praktek langsung. Teori berupa dasar instalasi listrik (umum dan dasar pemasangan instalasi listrik rumah tangga. Adapun praktek berupa pemasangan instalasi penerangan listrik rumah tangga. Untuk pelaksanaan praktek instalasi penerangan listrik rumah tangga membutuhkan sejumlah alat dan bahan sebagai berikut:

1) Kabel

2) Pipa PVC

3) Kotak cabang ( $\mathrm{T}$ dos dan cross dos) 
4) Saklar Tunggal dan Seri

5) Stop Kontak

6) L-bow untuk tikungan pada pipa

7) Mini Circuit Breaker (MCB)

8) Tang

9) Testpen

10) Obeng

11) Isolasi Strip

\subsection{Tahap Evalusi dan Tindak Lanjut}

1) Evaluasi terhadap hasil pelatihan melalui kousioner atau diskusi kelompok.

2) Bilamana prrogram ini setelah selesai maka komunikasi dengan mitra dan alumni pelatihan tetap akan dijaga.

\section{Hasil dan Diskusi}

Tahap pelaksanaan kegiatan dilakukan pada tanggal 6 Oktober 2019 bertempat di Aula Gedung Yayasan Azhar Center Makassar. Peserta pelatihan berasal dari mahasiswa Sekolah Tinggi Agama Islam (STAI) Al Azhar Gowa dan staf Madrasah Ibtidaiyyah Tahfidzul Qur'an (MITQ) dan Madrasah Tsanawiyah Tahfidzul Qur'an (MTsTQ) di bawah Yayasan Azhar Center.

Peserta terdaftar sebanyak 27 orang. Namun, peserta yang menyelesaikan pelatihan hingga tuntas dan mengisi kuesioner hanya sebanyak 21 orang. Semua peserta adalah laki-laki dengan usia berkisar antara $18-22$ tahun. Semua peserta memiliki pendidikian terakhir Sekolah Menengah Atas (SMA) atau sederajat. Tidak ada satu pun peserta yang memiliki latar pendidikan di bidang Teknik. Semua peserta bertempat tinggal di Kecamatan Manggala, Makassar.

Pelatihan dilakukan mulai dari jam 08.00 pagi - 18.00 sore. Pemateri teori terdiri dari 2 orang. Untuk praktikum didampingi oleh instruktur praktek sebanyak 4 orang. Materi teori terdiri atas dua sesi masing-masing selama 1,5 jam. Materi pertama adalah Dasar-Dasar Instalasi Listrik. Materi ke dua berjudul Pemasangan Instalasi Listrik Rumah Tangga. Untuk materi praktium dibatasi untuk instalasi penerangan listrik rumah tangga saja. Dalam pelaksanaannya praktikum dibagi menjadi 3 kelompok. Setiap kelompok dipandu oleh satu orang instruktur. Sementara, 1 orang instruktur berfungsi sebagai instruktur pengawas. Rundown kegiatan pelatihan ditunjukkan pada Tabel 1. Adapun visualisasi rangkaian kegiatan pelatihan ditunjukkan melalui Gambar 4. Setelah mengikuti kegiatan pelatihan, peserta diminta untuk mengisi kuesioner yang diikuti 21 orang. Daftar pertanyaan dan jawaban responden kuesioner disajikan pada Tabel 2.

Tabel 1. Rundown Kegiatan Pelatihan Instalasi Listrik Rumah Tangga

\begin{tabular}{|c|c|l|}
\hline No & Waktu & \multicolumn{1}{c|}{ Uraian Kegiatan } \\
\hline 1 & $08.00-08.30$ & Registrasi dan Persiapan \\
\hline 2 & $08.30-09.00$ & Pembukaan dan Orientasi Pelatihan \\
\hline 3 & $09.00-10.30$ & Teori 1 : Dasar-Dasar Instalasi Listrik \\
\hline 4 & $10.30-12.00$ & Teori 2 : Pemasangan Instalasi Listrik Rumah Tangga \\
\hline 5 & $13.00-15.00$ & Praktek : Instalasi Penerangan Listrk Rumah Tangga \\
\hline 6 & $15.30-17.30$ & Lanjutan Praktek : Instalasi Penerangan Listrk Rumah Tangga \\
\hline 7 & $17.30-17.45$ & Pengisian Kuesioner Pelatihan \\
\hline 8 & $17.45-18.00$ & Penutupan \\
\hline
\end{tabular}



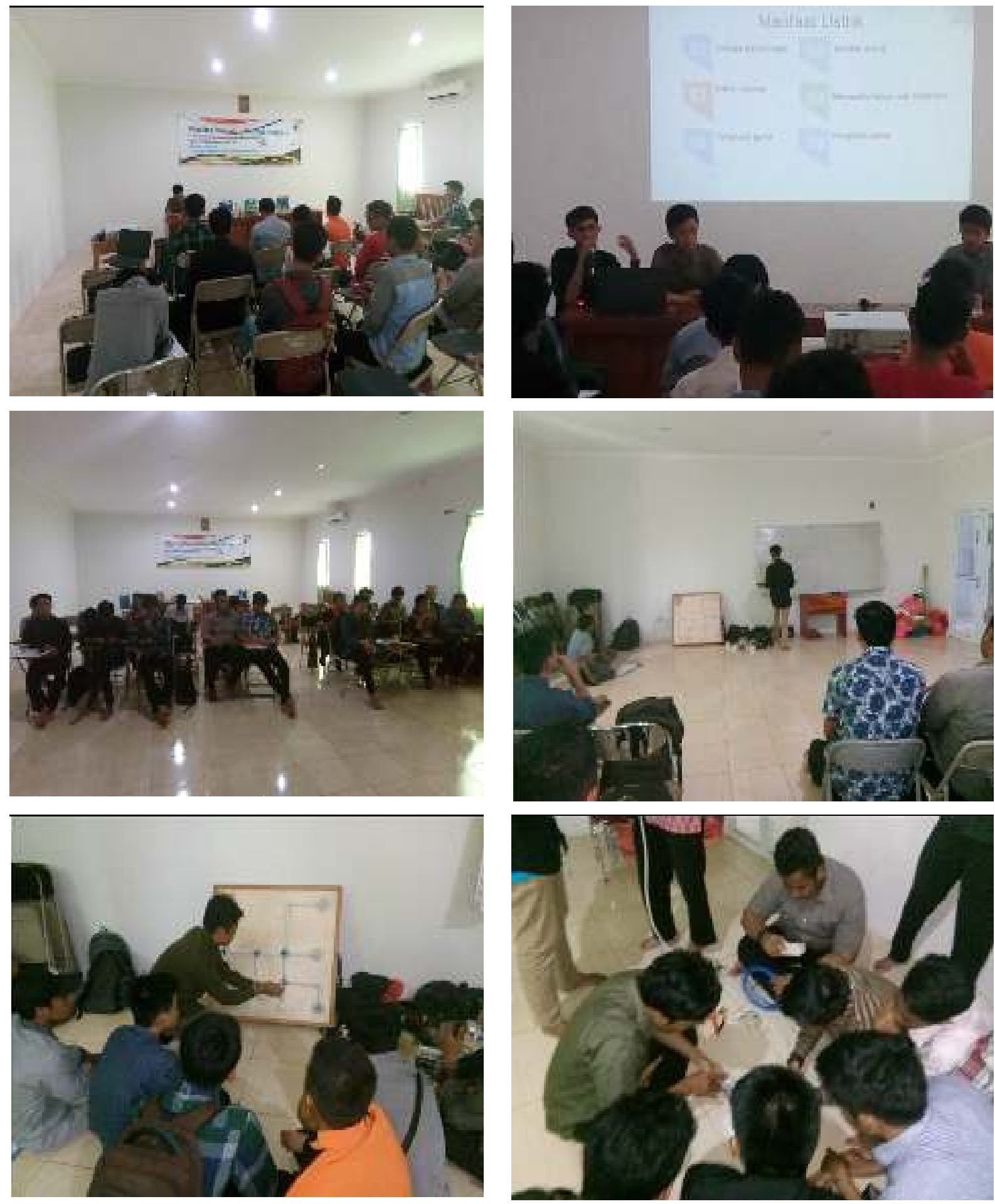

Gambar 4. Visualisasi Kegiatan Pelatihan Instalasi Listrik Rumah Tangga 
Tabel 2. Pertanyan dan Jawaban Kuesioner Pelatihan Instalasi Listrik Rumah Tangga

\begin{tabular}{|c|c|c|c|c|c|c|}
\hline \multirow[t]{2}{*}{ No } & \multirow[t]{2}{*}{ Pertanyaan } & \multicolumn{5}{|c|}{ Jawaban Responden Kuesioner (\%) } \\
\hline & & 1 & 2 & 3 & 4 & 5 \\
\hline 1 & $\begin{array}{l}\text { Sebelum mengikuti pelatihan, sejauhmana } \\
\text { pengetahuan anda mengenai materi yang } \\
\text { dilatihkan? }\end{array}$ & 33,3 & 57,1 & 4,8 & 4,8 & 0 \\
\hline 2 & $\begin{array}{l}\text { Apakah pemateri/instruktur pelatihan mampu } \\
\text { menyajikan materi yang jelas dan mudah untuk } \\
\text { dipahami? }\end{array}$ & 0 & 0 & 14,3 & 47,6 & 38,1 \\
\hline 3 & $\begin{array}{l}\text { Apakah modul pelatihan mencukupi untuk } \\
\text { memahami materi pelatihan ini? }\end{array}$ & 0 & 4,8 & 9,5 & 42,9 & 42,9 \\
\hline 4 & Apakah durasi waktu pelatihan cukup? & 4,8 & 61,9 & 28,6 & 23,8 & 33,3 \\
\hline 5 & $\begin{array}{l}\text { Setelah mengikuti materi pelatihan ini, seberapa } \\
\text { bermanfaat pelatihan ini buat anda? }\end{array}$ & 0 & 0 & 4,8 & 28,6 & 66,7 \\
\hline 6 & $\begin{array}{l}\text { Setelah mengikuti pelatihan, sejauhmana } \\
\text { peningkatan pengetahuan anda mengenai materi } \\
\text { yang dilatihkan? }\end{array}$ & 0 & 0 & 14,3 & 57,1 & 28,6 \\
\hline 7 & $\begin{array}{l}\text { Secara umum/keseluruhan, apakah pelatihan ini } \\
\text { berlangsung dengan baik sesuai dengan harapan } \\
\text { anda? }\end{array}$ & 0 & 0 & 0 & 28,6 & 71,4 \\
\hline \multicolumn{7}{|c|}{$\begin{array}{l}\text { Keterangan angka : } \\
\text { 1. Kurang Sekali } \\
\text { 2. Kurang } \\
\text { 3. Cukup } \\
\text { 4. Baik } \\
\text { 5. Baik Sekali } \\
\end{array}$} \\
\hline
\end{tabular}

Hasil kuesioner dijadikan dasar untuk mengevaluasi pelaksanaan pelatihan. Dari hasil kuesioner terlihat bahwa sebelum mengikuti pelatihan, pengetahuan sebagian peserta terkait instalasi listrik masih kurang. Hal ini ditunjukkan melalui pilihan jawaban kurang sekali sebanyak 33,3\% dan jawaban kurang sebanyak 57,1 \%. Kemampuan transfer materi dari pemateri dan instruktur menunjukkan angka yang baik (47,6 \% baik dan 38,1 \% baik sekali).

Adapun modul pelatihan dinilai baik oleh peserta (jawaban baik dan baik sekali masing-masing sebesar 42,9\%). Dari segi kemanfaatan, pelatihan ini dianggap bermanfaat oleh peserta $(28,7 \%$ menjawab baik dan $66,7 \%$ menjawab baik sekali). Peningkatan pengetahuan peserta setelah mengikuti pelatihan juga tergambar dari jawaban responden. Ada 28,6 \% yang menjawab baik sekali, 57,1 \% yang menjawab baik dan 14,3\% yang menjawab cukup.

Adapun pelaksanaan penelitian secara umum dianggap berjalan dengan baik $(28,6 \%$ baik dan $71,4 \%$ baik sekali). Khusus untuk durasi pelatihan, masih dirasakan kurang oleh mayoritas peserta. Ada 61,9 \% persen yang menyatakan kurang dan 4,8 \% menyatakan kurang sekali. Masalah durasi waktu ini menjadi titik utama evaluasi untuk pelaksanaan pelatihan instalasi listrik yang lebih baik lagi di masa mendatang. 


\section{Kesimpulan}

Pelatihan instalasi listrik rumah tangga untuk pemuda di Kecamatan Manggala Makassar telah berlangsung dengan baik. Sejumlah indikator berdasarkan hasil kuesioner menunjukkan hal tersebut. Indikator tersebut berupa bertambahnya tingkat pengetahuan peserta, penyajian materi, ketersediaan modul, kebermanfaatan pelatihan dan proses pelaksanan pelatihan secara keseluruhan.

\section{Ucapan Terima Kasih}

Ucapan terima kasih ditujukan kepada Fakultas Teknik Universitas Hasanuddin yang telah mendukung pendanaan kegiatan ini melalui Skim Pengabdian Masyarakat Laboratorium Based Education (LBE) 2019. Ucapan terima kasih juga ditujukan kepada Departemen Teknik Elektro Fakultas Teknik Universitas Hasanuddin yang telah mempercayakan pengelolaan program pengabdian masyarakat ini. Penghargaan juga disampaiakan kepada asisten Laboratorium Elektronika Daya serta mahasiswa Departemen Teknik Elektro Fakultas Teknik Universitas Hasanuddin yang telah membantu pelaksanaan kegiatan ini. Rasa terima kasih yang sebesarbesarnya juga disampaiakan kepada pengurus dan staf Yayasan Azhar Center Makassar serta STAI Al Azhar Gowa atas kerjasamanya dalam pelaksanaan kegiatan pengabdian masyarakat ini.

\section{Daftar Pustaka}

Badan Standarisasi Nasional (2000). Peraturan Umum Instalasi Listrik 2000 (PUIL 2000)

Harten, P.V., dan Setiawan, E., (1991). Instalasi Listrik Arus Kuat 1, Binacipta, Jakarta

Linsley, T., (2004). Instalasi Listrik Dasar, Erlangga, Jakarta

Muliyana R.Y., (2010). Dasar-Dasar Instalasi Listrik, terdapat pada laman https://rohmatyusufmuliyana.wordpress.com/elektro/dasar-dasar-instalasi-listrik, diakses pada 7 Oktober 2019

Zuhal (2000). Dasar Teknik Tenaga Listrik dan Elektronika Daya. PT. Gramedia Pustaka Utama, Jakarta. 